\title{
Hubungan Antara Penggunaan Gadget dengan Perkembangan Bahasa Anak Usia Dini
}

\author{
Arum Kusuma Dewi ${ }^{1}$, Yuyun Yulianingsih ${ }^{2}$, Tuti Hayati ${ }^{3}$ \\ 1,2,3Pendidikan Islam Anak Usia Dini, Universitas Islam Negeri Sunan Gunung Djati \\ Bandung \\ Jalan Soekarno Hatta Kel. Cimencrang, Gedebage Kota Bandung, Jawa Barat, Indonesia \\ Email: arumkusumadewi.akd@gmail.com¹,yuyunyulianingsih67@gmail.com², \\ hayatituti@yahoo.co.id ${ }^{3}$
}

Naskah diterima: 7 Januari 2019, direvisi: 19 Februari 2019, diterbitkan: 30 Maret 2019

\begin{abstract}
Abstrak
Hasil studi pendahuluan di kelompok B RA Al-Wafi menunjukkan bahwa, terdapat beberapa permasalahan yang terkait dengan penggunaan gadget dengan perkembangan bahasa diantaranya banyak orangtua yang mengandalkan gadget untuk membuat anaknya menjadi "anteng" atau tidak rewel dengan mempertontokan tayangan video ataupun membuka youtube. Tujuan penelitian ini adalah untuk mengetahui penggunaan gadget, perkembangan bahasa danhubungan antara penggunaan gadget dengan perkembangan bahasa anak usia dini. Metode yang digunakan yakni kuantitatif korelasional. Teknik pengumpulan data pada penelitian ini adalah melalui wawancara/bercakap-cakap dan observasi. Adapun hasil perhitungan pada variabel X diperoleh nilai rata-rata sebesar 1,76. Nilai tersebut berada pada interval 1,1 -2,0 dengan kategori cukup. Sedangkan, pada variabel Y diperoleh nilai rata-rata sebesar 2,66. Nilai tersebut berada pada interval 2,1 - 3,0 dengan kategori baik. Hubungan antara penggunaan gadget dengan perkembangan bahasa anak usia dini diperoleh angka koefisien korelasi sebesar 0,08. Angka koefisien korelasi ini termasuk pada kategori sangat lemah karena berada pada interval 0,000 - 0,199. Hasil uji signifikasi diperoleh harga thitung $=0,54$ lebih kecil dari harga $t_{\text {tabel }}=2,012$. Artinya $H_{0}$ diterima, dengan kata lain tidak terdapat hubungan positif yang signifikan antara penggunaan gadget dengan perkembangan bahasa anak usia dini. Adapun besarnya kontribusi/pengaruh penggunaan gadget terhadap perkembangan bahasa anak usia dini hanya 0,64\%. Hal ini menunjukkan bahwa 99,36\% perkembangan bahasa anak usia dini dipengaruhi oleh faktor lain.
\end{abstract}

Kata kunci: anakusiadini, gadget, perkembangan bahasa 


\begin{abstract}
The results of the preliminary study in $\mathrm{R} A \mathrm{Al}-W$ afi's group showed that, there were several problems related to the use of gadgets with language development including many parents who relied on gadgets to make their children become "calm" or not fussy by tipping video shows or opening youtube. The purpose of this study is to find out the use of gadgets; language development and the relationship between the use of gadgets and the development of early childhood language. The method used is quantitative correlation. Data collection techniques in this study were through interviews / conversations and observations. The results of calculations on variable $X$ obtained an average value of 1.76. This value is in the interval $1.1-2.0$ with sufficient categories. Whereas, the $Y$ variable obtained an average value of 2.66. This value is in the interval $2.1-3.0$ in the good category. The relationship between the use of gadgets and the development of early childhood language is obtained by the correlation coefficient of 0.08. This correlation coefficient number is included in the very weak category because it is in the interval 0,000 - 0,199. The results of the significance test obtained the price of tcount $=0.54$ smaller than the price of t table $=2.012$. This means that Ho is accepted, in other words there is no significant positive relationship between the use of gadgets and the development of early childhood language. The amount of contribution / influence of the use of gadgets to the development of the language of early childhood is only $0.64 \%$. This shows that $99.36 \%$ of language development in early childhood is influenced by other factors.
\end{abstract}

Keywords: early childhood, gadget, language development

\title{
Pendahuluan
}

Pendidikan anak usia dini (PAUD) adalah jenjang pendidikan sebelum pendidikan dasar yang merupakan suatu upaya pembinaan yang ditujukan bagi anak sejak lahir sampai dengan usia enam tahun, yang dilakukan melalui pemberian rangsangan pfendidikan untuk membantu pertumbuhan dan perkembangan jasmani dan rohani, agar anak memiliki kesiapan dalam memasuki pendidikan lebih lanjut. Pengertian pendidikan anak usia dini tersebut mengacu pada Undang-Undang Sikdiknas No. 20 Tahun 2003 Pasal 1 Ayat 14.Selanjutnya, pada Pasal 28 dinyatakan bahwa pendidikan anak usia dini dapat diselenggarakan melalui jalur pendidikan formal (taman kanak-kanak, raudatul athfal atau bentuk lain yang sederajat); jalur pendidikan nonformal (kelompok bermain, taman penitipan anak atau bentuk lain yang sederajat); dan/atau jalur informal yang berbentuk pendidikan 
keluarga atau pendidikan yang diselenggarakan oleh lingkungan (Musbikin, 2010). Dapat disimpulkan bahwa pendidikan anak usia dini adalah proses pemberian rangsangan pendidikan yang bertujuan untuk membina, menumbuhkan, dan mengembangkan seluruh potensi anak usia dini secara optimal sehingga terbentuk perilaku dan kemampuan dasar sesuai dengan tahap perkembangannya untuk memasuki jenjang pendidikan selanjutnya.

Perkembangan bahasa menjadi salah satu aspek terpenting dalam pendidikan anak usia dini karena bahasa akan memudahkan setiap individu dalam berkomunikasi. Bahasa adalah sarana berkomunikasi dengan orang lain. Dalam pengertian ini tercakup semua cara untuk berkomunikasi dimana pikiran dan perasaan dinyatakan dalam bentuk lisan, tulisan, isyarat atau gerak dengan kata-kata, simbol, lambang, gambar atau lukisan. Melalui bahasa, setiap manusia dapat mengenal dirinya, sesamanya, alam sekitar, ilmu pengetahuan dan nilai-nilai moral atau agama (Yusuf, 2011).

Manusia adalah makhluk sosial yang tak pernah lepas dari interaksi dan komunikasi dengan manusia lain. Seiring dengan berkembangnya zaman dan teknologi, manusia menciptakan sistem dan alat yang dapat mempermudah manusia saat berkomunikasi. Salah satu alat komunikasi yang paling berkembang pada saat ini adalah gadget. Di Indonesia, gadget merupakan barang yang hampir dimiliki oleh setiap orangbaik tua maupun muda bahkan anak-anak usia pendidikan dasar sudah banyak yangmenggunakannya.Kemajuan media informasi dan teknologi ini dirasakan oleh hampir seluruh lapisan masyarakat baik dari segi positif maupun negatifpenggunaannya. Hal ini karena mengakses media informasi dan teknologi ini tergolong sangat mudah, bahkan pada umumnya saat ini anak-anak usia 5-12 tahun menjadi pengguna yang paling banyak dalam memanfaatkan teknologi dan media informasi ini melalui gadget. Hal ini pun penulis temukan di lapangan. Saat ini banyak orangtua yang mengandalkan gadget untuk membuat anaknya menjadi "anteng" atau tidak rewel. Cukup dengan memberikan sebuah tablet atau handphone pada anak kemudian anak dibiarkan menggunakan gadget tersebut tanpa pengawasan. Kebanyakan anak-anak menggunakan gadget untuk melihat video atau bermain game. Namun tak dapat dipungkiri, ketika anak menggunakan gadget tanpa pengawasan anak dapat mengakses sesuatu yang seharusnya tidak terakses oleh mereka, seperti gambar atau video porno dan ini merupakan salah satu dari dampak negatif penggunaan gadget.

Dampak dari penggunaan gadget ini diibaratkan dua sisi mata uang, yakni memiliki dampak positif dan negatif. Dampak positif dari penggunaan gadget yakni dapat bertambahnya ilmu pengetahuan serta dapat meningkatkan kecerdasan pada seorang anak. Salah satu 
kecerdasan yang dapat ditingkatkan adalah kecerdasan bahasa. Adanya berbagai aplikasi digital seperti belajar mengenal huruf melalui lagu, belajar membaca melalui cerita pendek dan belajar menulis melalui teknik menebalkan huruf. Melalui aplikasi-aplikasi tersebut pemerolehan bahasa anak akan semakin bertambah melalui kosa kata baru yang mereka temukan.

Berdasarkan uraian di atas dan fenomena yang ditemukan di lapangan, peneliti tertarik untuk mengadakan penelitian, melalui sebuah judul: "Hubungan antara penggunaan gadget dengan perkembangan bahasa anak usia dini." Tujuan dari penelitian ini adalah untuk mengetahui adanya hubungan antara penggunaan gadget dengan perkembangan bahasa anak usia dini.

\section{Metodologi}

Pendekatan yang digunakan dalam penelitian ini adalah pendekatan kuantitatif. Pendekatan ini berlandaskan pada filsafat positivisme, yang digunakan untuk meneliti pada populasi atau sampel tertentu, dengan teknik pengambilan sampel pada umumnya dilakukan secara random, pengumpulan data menggunakan instrumen penelitian dan analisis data bersifat kuantitatif atau statistik dengan tujuan untuk menguji hipotesis yang telah ditetapkan (Sugiyono, 2017). Metode yang digunakan dalam penelitian ini adalah metode deskriptif. Metode deskiptif adalah metode penelitian yang berisi pemaparan atau penggambaran sesuatu. Metode deskriptif sendiri secara umum berisi uraian-uraian dan penjelasan panjang lebar mengenai objek yang diteliti (Muliawan, 2014).

Jenis data yang digunakan dalam penelitian ini adalah data primer, yakni data yang langsung diberikan kepada pengumpul data (Sugiyono, 2017). Data ini menyajikan penelitian berupa analisis pada data-data (numerical) yang diolah dengan metoda statistika.Penelitian ini dilaksanakan di kelompok B RA Al Wafi pada bulan November tahun 2018. Sumber data pada penelitian ini adalah siswa-siswi yang berjumlah 48 anak.

Teknik pengumpulan data yang digunakan adalah wawancara (bercakap-cakap) dan observasi. Wawancara (bercakap-cakap) merupakan teknik pengumpulan data yang dilaksanakan secara lisan dalam pertemuan tatap muka secara individual (Sukmadinata, 2017). Wawancara/bercakap-cakap yang digunakan adalah wawancara/bercakap-cakap terstruktur, yakni pengumpul data telah menyiapkan instrumen penelitian berupa pertanyaan-pertanyaan tertulis yang alternatif jawabannya pun telah disiapkan (Sugiyono, 2017). Percakapan ini 
digunakan untuk mengetahui bentuk penggunaan gadget pada anak usia dini. Pedoman wawancara/bercakap-cakap digunakan untuk menggali data tentang penggunaan gadget pada anak usia dini berupa lembar instrumen wawancara atau lembar instrumen bercakap-cakap. Skala pengukuran yang digunakan adalah skala likert dengan pemberian skor untuk pertanyaan bernilai positif yaitu; selalu diberi skor 4; sering diberi skor 3; kadang-kadang diberi skor 2 dan tidak pernah diberi skor 1. Sedangkan pemberian skor untuk pertanyaan nilai negatif yaitu; selalu diberi skor 1; sering diberi skor 3; kadang-kadang diberi skor 2 dan tidak pernah diberi skor 1.

Observasimerupakan suatu teknik atau cara mengumpulkan data dengan jalan mengadakan pengamatan terhadap kegiatan yang sedang berlangsung. Observasi yang dilakukan dalam penelitian ini adalah non partisipatif yakni pengamat tidak ikut serta dalam kegiatan, dia hanya berperan mengamati kegiatan (Sukmadinata, 2007). Observasi yang dilakukan dalam penelitian ini yaitu observasi terhadap perkembangan bahasa anak usia dini. Panduan observasi untuk menggali data tentang perkembangan bahasa anak usia dini berupa lembar observasi. Pemberian skor dalam lembar observasi dijabarkan sebagai berikut : a) BSB (Berkembang Sangat Baik) diberi skor 4; b) BSH (Berkembang Sesuai Harapan) diberi skor 3; c) MB (Mulai Berkembang) diberi skor 2; d) BB (BelumBerkembang) diberiskor 1.

Teknik analisis data yang digunakan dalam penelitian ini adalah teknik analisis data korelasional. Korelasi dapat didefinisikan sebagai hubungan timbal balik antara dua hal atau lebih, atau keadaan saling ketergantungan dua variabel yang dihitung secara kuantitas. Lebih jelasnya, korelasi adalah suatu teknik untuk mengukur tingkat koefisien hubungan dan pengaruh antara dua variabel. Koefisien korelasi itu digunakan untuk mengukur derajat hubungan dan pengaruh variabel X dengan variabel Y. Variabel X (variabel bebas) pada penelitian ini adalah penggunaan gadget, sedangkan variabel Y (variabel terikat) pada penelitian ini adalah perkembangan bahasa anak usia dini (Hayati, 2014).

Analisis data dilakukan melalui menggunakan langkah-langkah berikut: 1) Uji Validitas, validitas adalah suatu ukuran yang menunjukkan tingkat kevalidan atau kesahihan suatu instrumen. Suatu instrumen yang valid atau sahih mempunyai validitas tinggi. Sebaliknya, instrumen yang kurang valid berarti memiliki validitas rendah (Arikunto, 2013). 2) Uji Reliabilitas, reliabilitas menunjuk pada satu pengertian bahwa sesuatu instrumen cukup dapat dipercaya untuk digunakan sebagai alat pengumpul data karena instrumen tersebut sudah baik.3) Analisis Parsial, analisis ini dimaksudkan untuk menguji dan menghitung skorratarata indikator variabel $\mathrm{X}$ dan variabel $\mathrm{Y}$. 4) Analisis Korelasi, koefisien korelasi adalah 
bilangan atau angka yang menyatakan besar kecilnya hubungan. Koefisien korelasi itu bergerak antar 0,00sampai $+1,00$ atau antara 0,00 sampai $-1,00$ atau $+1,00$ sampai $-1,00$. Koefisien yang bertanda positif menunjukkan arah korelasi positif dan koefisien negative menunjukkan arah korelasi negatif. Sedangkan koefisien yang bernilai 0,00 menunjukkan tidak ada hubungan antar variabel X dengan variabel Y (Hayati, 2016). Koefisien korelasi biasanya diberi simbol r (korelasi Product Moment) atau @ (dibaca rho, korelasi Rank) dan karena kedua komponen masing-masing ditandai dengan huruf $\mathrm{X}$ dan $\mathrm{Y}$, maka koefisien korelasinya disingkat menjadi rxy. Oleh karena itu setelah data terkumpul, sebelum menilai hubungan antara dua variabel yang diteliti, harus dihitung terlebih dahulu koefisien korelasinya.Berdasarkan ketentuan di atas mengenai persyaratan analisis statistik parametris, maka data yang diperoleh diuji normalitas danregresi linier terlebih dahulu untuk mengetahui data tersebut berdistribusi normal atau tidak menggunakan Chi Kuadrat $\left(\chi^{2}\right)$.

\section{Hasil dan Diskusi}

Berdasarkan hasil penelitian, penggunaan gadget pada anak-anak kelompok B di RA AlWafi masih termasuk kategori cukup. Hal in terlihat dari analisis parsial yang menunjukkan bahwa nilai rata-rata penggunaan gadget adalah 1,76 dan berada pada interval 1,00-2,00 yang artinya cukup.

Sementara itu, berdasarkan hasil perhitungan diperoleh mean $=34,33$; dan standar deviasi $=4,95$, nilai chi kuadrat $\left(\chi^{2}\right)$ hitung $=54,333 ;$ dan chi kuadrat $\left(\chi^{2}\right)$ tabel $=2,776$ dengan $\mathrm{db}=4$ pada taraf signifikansi $5 \%$. Karena $\left(\chi^{2}\right)$ hitung $=54,333>\left(\chi^{2}\right)$ tabel $=2,776$, maka data tentang penggunaan gadget berdistribusi tidak normal.

Pengenalan atau penggunaan gadget terlalu dini pada anak dapat memberikan dampak positif maupun negatif. Hal tersebut dipengaruhi oleh beberapa faktor seperti frekuensi, durasi, dan pengawasan orang tua. Penggunaan gadget sebagai bahan dasar pembelajaran pada anak akan berdampak positif seperti meningkatkan kreativitas dan daya pikir anak. Hal tersebut dapat muncul apabila orang tua pandai mengontrol dan mengarahkan anak, serta tegas dalam memberikan batasan-batasan waktu kepada anak dalam bermain gadget. Begitupun sebaliknya, apabila pengawasan orang tua kurang serta tidak ada upaya tegas dalam memberikan batasan waktu bermain gadget pada anak, dapat menimbulkan sisi negatif. Hal tersebut sesuai dengan hasil penelitian yang dilakukan oleh Salsabila bahwa terdapat 
pengaruh antara lama penggunaan gadget terhadap perkembangan anak di TK Al-Azhar Banda Aceh.

Selanjutnya berdasarkan hasil penelitian terhadap perkembangan bahasa secara keseluruhan, perkembangan bahasa anak usia dini di kelompok B RA Al-Wafi sudah termasuk ke dalam kategori baik. Hal ini ditunjukkan dari analisis parsial yang menunjukkan angka 2,66 yang berada pada interval 2,00 - 3,00 yang artinya berkualifikasi baik.

Hasil perhitungan perkembangan bahasa anak usia dini diperoleh mean $=47,81$; standar deviasi $=9,83$; nilai chi kuadrat $\left(\chi^{2}\right)$ hitung $=19,12$; dan chi kuadrat $\left(\chi^{2}\right)$ tabel $=4,303$ dengan $\mathrm{db}=2$ pada taraf signifikansi 5\%. Karena $\left(\chi^{2}\right)$ hitung $=19,12>\left(\chi^{2}\right)$ tabel $=4,303$, maka data tentang perkembangan bahasa anak usia dini berdistribusi tidak normal.

Berdasarkan hasil observasi sebagian besar responden memiliki perkembangan bahasa yang baik, namun ada beberapa anak yang perkembangan bahasanya belum maksimal. Hal ini dikarenakan karena beberapa faktor diantaranya motivasi dan stimulus yang diberikan masih kurang dan pemerolehan bahasa yang didapat masih minim. Hal ini sejalan dengan teori yang dikemukakan Gagne yakni peringkat proses pembelajaran melalaui delapan fase; 1) motivasi, 2) pemahaman, 3) pemerolehan, 4) penahanan, 5) ingatan kembali, 6) generalisasi, 7) perlakuan dan 8) umpan balik.

Hasil penentuan harga koefisian korelasi, besarnya hubungan antara penggunaan gadget dengan perkembangan bahasa sebesar 0,08 angka tersebut berada pada interval 0,00 - 0,199 yang artinya memiliki hubungan yang sangat lemah antara penggunaan gadget dengan perkembangan bahasa anak usia dini. Dilihat dari hasil perhitungan diperoleh $t_{\text {hitung }}=0,54$ dengan taraf signifikansi 5\% dan untuk diuji derajat kebebasannya sehingga diperoleh $t_{\text {tabel }}=$ 2,012 yang menunjukkan $t_{\text {hitung }}<\mathrm{t}_{\text {tabel}}$, maka Ho diterima dan Ha ditolak yang artinya tidak terdapat hubungan positif yang signifikan antara penggunaan gadget dengan perkembangan bahasa anak usia dini. Artinya hubungan antara penggunaangadget dan perkembangan bahasa anak usia dini ini termasuk ke dalam kategori sangat lemah karena berdasarkan penelitian, aplikasi yang biasa digunakan oleh anak adalah aplikasi game, game yang sering dimainkan bukanlah game edukatif sehingga pemerolehan bahasa yang diperoleh saat bermain game sangatlah kurang. Selain aplikasi game, youtube juga menjadi salah satu aplikasi yang paling mereka sukai karena melalui aplikasi tersebut mereka dapat melihat video-video.

Namun sangat disayangkan, anak cenderung lebih banyak menonton video yang tidak bernilai edukatif, sebagai salah satu contohnya adalah menonton video dari Black Pink yakni salah satu girl band asal Korea. Dalam video tersebut anak memperoleh pengetahuan bahasa 
baru yakni mengetahui bahasa Korea melalui lirik lagu yang diperdengarkan, hanya saja di dalam video tersebut dirasa kurang pas jika ditonton oleh anak usia 5 - 6 tahun karena bisa menimbulkan dampak negatif yakni terpaparnya konten pornografi. Penggunaan gadget sebagai alternatif media pembelajaran yang edukatif pun dirasa masih sangat kurang.

Dalam penggunaannya orangtua seharusnya mengarahkan anak kepada educational games. Educational games adalah penggabungan dari manfaat prinsip game dengan teknologi untuk menghasilkan sebuah konten edukasi (educational content) yang di dalamnya dimasukkan unsur menyenangkan (fun) ke dalam suatu pembelajaran (Zemliansky dan Wilcox, 2010). Perkembangan jaman juga telah mendorong pembentukkan aplikasi-aplikasi yang dapat mendukung anak-anak untuk mau belajar dengan cara yang lebih menyenangkan.

Mark Blades, Fran C. Blumberg, dan Caroline Oates (2013) menerangkan bahwa melalui game, anak dapat termotivasi untuk belajar dengan konsep baru dalam konteks yang menghibur dan menyenangkan. Monica Monk dkk (2013) juga menyatakan dalam penelitiannya bahwa game memiliki kekuatan yang dapat mendorong peningkatan aktivitas serta memotivasi anak dalam melakukan suatu aktivitas dengan menyenangkan dan mengadaptasi cara belajar anak yang menyenangkan melalui game. Dengan memanfaatkan teknologi yang ada, kita dapat menciptakan sebuah game yang tidak hanya mengajak anakanak untuk sekedar bermain tanpa mendapatkan ilmu, namun kita dapat menciptakan sebuah permainan yang secara tidak langsung dapat memberikan ilmu pengetahuan bag ianak.

\section{Penutup}

Berdasarkan hasil perhitungan dapat disimpulkan bahwa: 1) Penggunaan gadget di kelompok B RA Al Wafi Kecamatan Panyileukan Kota Bandung berkualifikasi cukup. 2) Penggunaan perkembangan bahasa anak usia dini di kelompok B RA Al Wafi Kecamatan Panyileukan Kota Bandung berkualifikasi baik. 3) Hubungan antara penggunaan gadget dengan perkembangan bahasa anak usia dini berada pada kategori sangat lemah. Hasil uji signifikansi lebih kecil dari harga $t_{\text {tabel }}$. Artinya $\mathrm{H}_{\mathrm{o}}$ diterima, dengan kata lain tidak terdapat hubungan positif yang signifikan antara penggunaan gadget dengan perkembangan bahasa anak usia dini.

Berdasarkan hasil penelitian yang dilakukan, ada beberapa saran yang dapat menjadi pertimbangan bagi pihak-pihak yang bersangkutan, diantaranya sebagai berikut: 1) Bagi pendidik maupun orangtua diharapkan agar dapat mendampingi anaknya saat menggunakan gadget. Hal ini dikarenakan penggunaan gadget yang tidak terawasi akan lebih banyak 
menimbulkan dampak negatif yang lebih besar. 2) Bagi mahasiswa/i Program Studi Pendidikan Islam Anak Usia Dini yang memiliki ketertarikan ingin meneliti variabel yang sama, sebaiknya terlebih dahulu mengkaji hasil-hasil penelitian yang sudah ada atau dari hasil penelitian sebelumnya, agar penelitian tersebut dapat menghasilkan temuan-temuan baru yang nantinya akan saling melengkapi dengan temuan-temuan sebelumnya dan juga dapat menjadi perbandingan bagi penelitian selanjutnya.

\section{Daftar Pustaka}

Abdullah, I. \& Darmawan, D. (2013). Teknologi Pendidikan. Bandung: Remaja Rosdakarya.

Aisah, S. \& Hidayat, H. (2015). Aktivitas Mengajar Anak TK/RA dan PAUD. Bandung: Arvino Raya.

Arikunto, S. (2013). Prosedur Penelitian (Suatu Pendekatan Praktik). Jakarta: Rineka Cipta.

Djamarah, S. B. (2011). Psikologi Belajar. Jakarta: Rineka Cipta.

Hayati, T. (2016). Pengantar Statistika Pendidikan. Bandung: Insan Mandiri.

Ismawati, E. \& Umaya, F. (2012). Belajar Bahasa di Kelas Awal. Yogyakarta: Ombak.

Imam Musbikin. (2010). Buku Pintar PAUD (DalamPerspektif Islam). Yogyakarta: Laksana

Iskandarwwasid dan Sunendar, D. (2008). Strategi Pembelajaran Babasa. Bandung: Remaja Rosdakarya.

Latif, M., dkk. (2013). Orientasi Baru Pendidikan Anak Usia Dini (Teori dan Aplikasi). Jakarta: Kencana.

Muliawan, J. U. (2014). Metode Penelitian Pendidikan. Yogyakarta: Gava Media.

Madyawati, L. (2016). Strategi Pengembangan Bahasa Pada Anak. Jakarta: Prenadamedia Group.

Nurihsan, A. J. \& Agustin, M. (2011). Dinamika Perkembangan Anak dan Remaja (Tinjauan Psikologi, Pendidikan dan Bimbingan). Bandung: Refika Aditama.

Orange dan O’Flynn. (2007). The Media Diet for Kids. Jakarta: PT Serambi Ilmu Semesta.

Peraturan Menteri Pendidikan dan Kebudayaan Republik Indonesia Nomor 137 Tahun 2014 Tentang Standar Nasional Pendidikan Anak Usia Dini.

Ratuliu, M. (2018). Digital ParenThink. Jakarta: Mizan Publika.

Siregar, S. (2013). Metode Penelitian Kuantitatif. Bandung: Kencana.

Sugiyono. (2015). Statistika Untuk Penelitian. Bandung: Alfabeta.

Sugiyono. (2017). Metode Penelitian Pendidikan. Bandung: Alfabeta.

Sukmadinata, N. S. (2005). Metode Penelitian Pendidikan. Bandung: Remaja Rosdakarya.

Sundayana, R. (2016). Statistika Penelitian Pendidikan. Bandung: Alfabeta 
Suyadi dan Ulfah, M. (2013). Konsep Dasar PAUD. Bandung: Remaja Rosdakarya.

Syah, M. (2003). Psikologi Belajar. Depok: Raja Grafindo Persada.

Undang-Undang Sikdiknas No. 20 Tahun 2003 Pasal 1 Ayat 14

Yusuf, S. (2011). Perkembangan Peserta Didik. Depok: Rajawali Pers. 